\title{
ASPECTOS JURÍDICOS DA MODA: ANÁLISE CRÍTICA DO FASHION LAW NO BRASIL
}

\section{Taís Tavares Vieira Pessoa}

Graduanda em Direito pelo Centro Universitário Christus (Unichristus). Bolsista de Iniciação Científica, sob a orientação da Profa. Ma. Camila Figueiredo Oliveira Gonçalves. Estagiária do TJ-CE na Comarca de Caucaia. taistavaresvp@gmail.com

\section{Camila Figueiredo Oliveira Gonçalves}

Mestra em Direito Constitucional nas Relações Privadas pela Universidade de Fortaleza. Coordenadora e Professora de Direito Civil do Unichristus. camilafogoncalves@gmail.com

\section{INTRODUÇÃO}

O Direito, enquanto ciência social, é (rectius, deve ser) um ramo do conhecimento dinâmico, devendo se modificar constantemente para atender satisfatoriamente as necessidades que emergem na sociedade. Em vista dessa não perenidade devido aos influxos sociais, novas áreas de estudo surgem a partir das demandas postas pelo homem no seu constante processo de evolução (PERLINGIERI, 2002). Assim, ramos como Biodireito, Direito do Mar, Direito Virtual se desenvolvem como vias de tutela da pessoa em suas várias facetas. Todavia, ainda há áreas que precisam de regulamentação própria, como a moda.

O estudo da moda é, muitas vezes, desprezado pelos pesquisadores científicos, por ser considerado um ramo superficial (GODART, 2010). Entretanto, é um fenômeno que vem acompanhando a sociedade e seus modelos econômicos, exercendo uma crescente influência em áreas do consumo (SVENDSEN, 2010).

A moda se faz presente nas relações industriais e sociais, e isso pode ser percebido em pesquisas feitas pelo IBOPE, as quais afirmam que, no ano de 2013, o consumo esperado per capita de roupas era de $\mathrm{R} \$ 786,39$. Devido a esse crescimento constante, a moda passou a ser vista como fato social (GODART, 2010), pois, além de ser artística, econômica e política, é um fator de identidade pessoal.

Ao se classificar a moda como um fato social, pode-se afirmar que o Direito não deve ser alheio a esse fenômeno. Assim, faz-se mister a existência de uma regulamentação específica para as relações decorrentes da moda, o que justifica o aprofundamento dos estudos relacionados a elas. 
Com a pesquisa em desenvolvimento, pretende-se estudar o emergente ramo do Direito da Moda e sua abordagem no Brasil, verificando quais as principais áreas atingidas e suas conexões. Isso será realizado mediante pesquisa documental e bibliográfica, bem como por pesquisa de campo, na qual serão feitas entrevistas com profissionais da moda e do Direito, para que possam expor suas opiniões, e o método da pesquisa será o dedutivo. O estudo será iniciado com uma análise histórica da moda, para, depois, responder-se à seguinte pergunta de partida: como tutelar direitos inerentes à pessoa, como os direitos da personalidade, no ramo da moda?

\section{Referencial Teórico}

A palavra moda vem do latim modus, que significa, também, forma de conduzir. Foi no século XV que os franceses começaram a utilizar mode (modo), que fazia referência aos gostos e às preferências das pessoas, bem como à maneira que elas se vestiam (POLLINI, 2007).

Entretanto, foi na Renascença o momento em que a moda se destacou (GODART, 2010), pois, mesmo em vista da ruptura com as estruturas próprias do medievo, as pessoas passaram a ostentar a riqueza e, a partir disso, competir. Consequentemente, o Estado e a Igreja, desejando controlar essas atitudes, tomaram providências, como a criação das leis suntuárias. Essas leis reservavam o uso de certos trajes e acessórios a classes específicas, não podendo classes inferiores os adquirir, mesmo que possuíssem recursos. Porém, a proibição aparentemente tornava os objetos mais atraentes, e as leis eram violadas, o que demonstrava o papel das roupas como um importante termômetro do status social (SVEDSEN, 2010).

Com a chegada do século XIX, as classes baixas foram atraídas para o mundo da moda, devido à produção em massa. A partir disso, a moda passou a ser uma forma de afirmação da individualidade, visto que existia, também, uma alta produção de acessórios, permitindo que as pessoas demonstrassem sua personalidade (SVENDSEN, 2010).

Assim, é possível visualizar que a moda adquire um importante espaço tanto no mercado de consumo, como na formação da identidade pessoal, demarcando a individualidade do sujeito consigo e com a sociedade (SVEDSEN, 2010). Na contemporaneidade, a maioria das pessoas pode ter acesso à moda, independentemente da sua condição social, sexo ou etnia, mostrando que o conceito atual de moda foi reformulado enquanto fato social, tendo, portanto, repercussões jurídicas relevantes que merecem análise. Tanto assim o é que, segundo uma pesquisa do Pyxis-Consumo IBOPE, a perspectiva do consumo de roupas no ano de 2013 no Brasil era de R\$ 129 bilhões (IBOPE, 2013).

Devido a essa importância econômica com impactos jurídicos, a moda passou a ser mais estudada, existindo, por exemplo, nos Estados Unidos, uma área do Direito em crescimento intitulada Fashion Law (Direito da Moda) (JIMENEZ; KOLSUN, 2014), a qual começou a se estruturar no Brasil, visto que São Paulo é considerada a oitava capital mundial da moda ${ }^{1}$.

Pode-se afirmar, então, que, com o decorrer do tempo, as relações advindas da moda vêm se complexificando, o que gera um aumento de conflitos (IBAIXE JR; SABÓIA, 2014). Sabendo disso, faz-se mister a existência de uma proteção adequada, objetivando a garantia dos direitos dos indivíduos neles envolvidos.

1 Existe, em São Paulo, uma Comissão própria na Ordem dos Advogados do Brasil (OAB) intitulada Comissão de Estudos em Direito da Moda. 


\section{Proposta de Desdobramentos da Pesquisa}

A pesquisa, em andamento, intitulada "Aspectos jurídicos da moda: análise crítica do Fashion Law no Brasil”, tem como objetivo principal analisar a proteção dos direitos, principalmente da personalidade, nesse novo ramo jurídico, investigando sua interação com a moda e a efetivação de sua garantia.

O seu desenvolvimento começará de uma análise histórica, abordando as origens da moda e sua etimologia, até a sua conceituação como fato social total. A partir disso, será estudada a sua interação com a sociedade, com o mercado e, consequentemente, com o Direito. Ao final, será abordado o Direito da Moda, investigando sua relação com outras áreas jurídicas, como Direito Empresarial, o Direito Penal e a Responsabilidade Civil, para analisar a possibilidade da moda como um ramo autônomo e como pode ser efetivada a proteção dos relacionamentos advindos dela.

\section{Resultados Esperados}

Ao final do trabalho, pretende-se entender melhor o desenvolvimento do Fashion Law no Brasil, sua interação com os Direitos da Personalidade e como a efetiva tutela deles pode ser realizada, uma vez que, devido a sua característica comunicativa, ninguém está imune à moda (POLLINI, 2007).

Almeja-se verificar a interação da moda nos Direitos da Personalidade, especialmente no Direito à Imagem (SCHREIBER, 2013), analisando as hipóteses de proteção desse, quais sejam (ABREU, 2014):

- Como manifestação do direito ao próprio corpo;

- Como expressão do direito à intimidade;

- Como objeto de proteção da honra;

- Como poder de autodeterminação individual;

- Como manifestação da individualidade.

Pretende-se, também, analisar a moda no Direito Empresarial enquanto Propriedade Industrial, que tutela o desenho industrial e a marca (BERTOLDI, 2014); e no Direito Penal, que possui um capítulo intitulado Dos Crimes contra a Propriedade Imaterial que visa à proteção da Propriedade Intelectual (BITENCOURT, 2014).

\section{Considerações Finais}

A pesquisa que se pretende desenvolver com o projeto surge dos questionamentos abordados anteriormente e da necessidade de tutelar direitos inerentes ao indivíduo, visando garantir a dignidade da pessoa humana nas relações decorrentes do direito da moda.

\section{REFERÊNCIAS}

ABREU, Lígia Carvalho. $\mathrm{O}$ direito à imagem como matéria fundamental do Direito da Moda. Disponível em: <http://revistas.ulusofona.pt/index.php/rfdulp/article/view/4347>. Acesso em: 09 nov. 2014. 
BERTOLDI, Marcelo M., Curso Avançado de Direito Comercial. 8. ed. São Paulo: Revista dos Tribunais, 2014.

BITENCOURT, Cezar Roberto. Tratado de Direito Penal. 10. ed. São Paulo: Saraiva, 2014, v. 3. GODART, Frédéric. Sociologia da Moda. São Paulo: Senac, 2010.

IBAIXE JR, João; SABÓIA, Valquíria. Direito da Moda: um ramo jurídico em construção? In: Migalhas. São Paulo, 23 jun. 2014. Disponível em: <http://www.migalhas.com.br/ dePeso/16,MI203163,71043-Direito+da+Moda+um+ramo+juridico+em+construcao $>$. Acesso em: 06 nov. 2014.

IBOPE. O mercado de moda brasileiro. 2013. Disponível em: <http://www.ibope.com.br/ pt-br/conhecimento/Infograficos/Paginas/Mercado-de-moda-brasileiro.aspx $>$. Acesso em: 06 nov. 2014.

JIMENEZ, Guillermo C.; KOLSUN, Barbara. Fashion Law: A guide for Designers, Fashion Executives and Attorneys. New York: Fairchild Books, 2014.

PERLINGIERI, Pietro. Perfis de Direito Civil. 2. ed. Rio de Janeiro: Renovar, 2002.

POLLINI, Denise. Breve história da Moda. São Paulo: 2007.

SCHREIBER, Anderson. Direitos da Personalidade. 2. ed. São Paulo: Atlas, 2013.

SVEDSEN, Lars. Moda: uma filosofia. Rio de Janeiro: Zahar, 2010. 